\title{
ASSISTANCE OF THE PSYCHOLOGIST EXPERT IN THE JUSTICE BODIES TO PROTECT MINORS IN KOSOVO
}

\author{
Elda Maloku \\ Department of Criminal Law \\ malokuelda@gmail.com \\ Osman Jasarevic \\ Department of Criminal Law \\ Univerisity in Travnik \\ 5 Aleja Konzula str., Travnik, Bosnia and Herzegovina, 72270 \\ dr.osmanjasarevic@hotmail.com \\ Ahmet Maloku \\ Department of Criminology ${ }^{l}$ \\ malokuahmet@gmail.com \\ ${ }^{1}$ Iliria University \\ 75 Gazmend Zajmi str., Prishtinë, Kosovo, 10060
}

\begin{abstract}
This paper reviews the assistance of a psychologist expert in the justice bodies to protect minors in Kosovo. Research data on the study of normative acts (laws and international acts) regarding the role of the expert psychologist have been analyzed since from September 1999 until 2019. The purpose of this study is to assess the role of an expert psychologist, conforming to national and international legal norms in the protection of minors at the police, prosecution and court organs, where the analysis of these legal norms has been used over the years. In the case of looking at the protection of minors the expert psychologist is involved in all stages of criminal and civil proceedings before the competent authorities. The results show that the role of the psychologist expert in justice bodies in Kosovo is based on national and international law, but in this highly sensitive work Kosovo psychologist experts must have their own association to represent their requests as good as possible to the competent authorities and for the delegation of the name of the expert psychologist at the request of the judge. Moreover, it has been found that until now the determination of the expert psychologist hired has been made with the will of the judge. This paper contributes to existing scientific literature, especially in the fields of criminology, victimology and forensic psychology. Moreover, this paper is likely to contribute to the work of the Association of Psychological Experts, the Victims' Association and in the work of various minors' protection associations.

Keywords: juvenile, forensic psychologist, sociologist, social worker, civil procedure, criminal procedure.
\end{abstract}

DOI: $10.21303 / 2504-5571.2021 .001649$

\section{Introduction}

Knowing that the testimony of juveniles at the competent bodies may be correct and incorrect; untrue and false, therefore it is unacceptable to generalize that a child's or juvenile's testimony should at first be considered less reliable or less true than the testimony of an adult. Thus, all testimonies must be verified and evaluated, regardless if it is the testimony of a child, a minor, or the testimony of witnesses and adult participants. However, it is another matter whether children and juveniles should be invited in the court trial, when this can have a psychologically adverse effect (eg. on penal offenses of cousins, incest, etc) [1, p. 25]. At the age of puberty, declarations are uncertain because boys are more likely to emphasize feelings of boastfulness, conceit, or anger, and interpret their perceptions from the angle of a common attitude characteristic of their peers. Girls at puberty, meanwhile, are confused by sexual instinct and interpret their perceptions from a personal egocentric perspective.

Vodinelić \& Aleksić [2] states out that children also have so-called eidetic, which he says, are the most perfect witnesses ever existed. Eidetic memory is a special ability of perception and remembering. Eidetic are usually children up to the age of 15, who have the ability to remember 
events in the form of clear optical (images) stories and describe them in the finer details that adults would not have noticed them at all.

The European Convention on Human Rights, the Convention on the Rights of the Child, the UN Standard Minimum Rules for the Application of Juvenile Court Proceedings, and the legal framework of Kosovo are fundamental guarantees for the rights of juveniles to have a child psychologist expert or a social worker during the investigation procedure and during the testimony in the Court. This legal framework allows the psychological assessment of juveniles to be as correct and real as possible, as well as the situation in which the juvenile is located.

Kosovo covered the post-war legal vacuum by regulations, two Codes were adopted in 2003: the Provisional Criminal Code [3], and the Provisional Criminal Procedure Code [4] which entered into force on April 6, 2004. Also in the same year, the Assembly of Kosovo adopted the Juvenile Justice Code of Kosovo [5], which entered into force on April 20, 2004. While in 2006, the Parliament of Kosovo adopted the Law on Family [6], which at the same time gave greater support and security to civil court processes in various procedures, especially to family procedures, where juvenile delinquency is involved in different disputes. The well-being of family processes, especially those that are very harmful to minors, such as divorce, the right to custody, the abolition of parental responsibility, etc., now it would easier with the involvement of a psychologist or social worker in protecting minors in procedures, investigations at the police, prosecution or civil and criminal court procedures. Forensic psychology is a branch of applied psychology, directed at collecting, researching, diagnosing and presenting evidence for the needs of the courts, whether those are in the field of family, civil or criminal aspect. Minor is considered a person between the ages of fourteen (14) and eighteen (18) years. Cases, requiring the juvenile to be involved in all procedural and judicial steps, since his or her interrogation by a police investigator, prosecutor or court, showed some deficiencies, which forced the legislative bodies to adopt the Juvenile Justice Code [7], to protect the right of the juvenile during all civil and criminal procedural stages.

The Juvenile Justice Code decided at the center of the legal issue the conduct of a psychological assessment by a psychologist and an assessment of the family social situation by a social worker or sociologist.

Understanding the importance of the role of the psychologist expert during all stages of criminal and civil procedure and both civil and criminal judgment, Kosovo's legal framework is aligned with international conventions by ensuring the juvenile and the litigants to be involved in the investigative and judicial processes by the psychologist expert.

Aim of research. The purpose of this study is to assess the role of an expert psychologist, conforming to national and international legal norms in the protection of minors at the police, prosecution and court organs.

\section{Research methodology}

This study is based on the use of numerous research methods. The particular scientific methods, used in this, paper are primarily the method of analysis and synthesis, which will be particularly useful when researching the theoretical views of domestic and foreign authors, who have studied and analyzed the role of the expert psychologist in the justice authorities for protection of minors in Kosovo.

In similar circumstances, the induction and deduction method is also used. Since the role of the psychologist expert is a complex category that can be analyzed in many aspects, each of which demonstrates the complexity itself, and thus the activities are associated with its solutions, we will use the classification method in this paper. Content analysis as a necessary method will be used to study the numerous literatures, in which this problem has been addressed in various respects. This method is unavoidable in the study of normative acts (laws and international acts).

\section{Research results and discussion}

Research in the field of the role of the psychologist expert in the police, prosecution and court bodies to protect juveniles in Kosovo is presented in various studies by lawyers, criminologists, psychologists and sociologists. In a report, compiled by the Center for Civic Legal Initiatives (CLCI) and the Free Legal Service [8], we see that it was sufficiently analyzed: the role of Albanian legislation for 
the participation of the psychologist in the judicial system (the civil and criminal process); The role of the psychologist expert in litigation for the protection of the best interests of the child; Organization of psychologist/social worker expertise service. Albania's experience; Experience of free legal service centers (CLCI, TLAS) in identifying some problems in the expertise of the psychologist/social worker towards children and litigants; as well as a list of real problems that arises during the legal process in Albanian courts. A professor from the University of Sarajevo Hasković [9] has researched and analyzed the behavioral psychology and developing informational conversation with children and minors as well as the behavioral tactics and developing informative conversation with children and minors. This research has helped enormously the prosecution authorities, such as the police and the prosecution to be more prepared during the informational conversation with juveniles. The author Hasković [9] also shows that children are inclined to imagine, because they are filled with different passions and desires, with little opportunity. They often lose their sense of reality, mixing real and defamatory events and situations. Children are subjected to suggestions, so adults often manipulate with them. It is possible to impose a version of the event that in fact it did not happen. On the contrary to this, children can be quite clingy and stubborn in defending their own opinion because in this way they try and oppose the authorities and the older ones. At the time of puberty, their statements are uncertain because children are distinguished by their sense of pride, all-knowingness and opposition. Girls are exposed to the ambiguous impact of gender passion, so the observations are interpreted in an egocentric and autistic way. We should be especially careful when girls or underage girls complain of sexual harassment, as this may be inaccurate as a result of particular moods.

In extensive research in the literature, Sutherland explains in further that in areas where delinquency is high, the juvenile, who is social and active, seems so much likely to be in contact with the neighborhood and choose delinquent behavior. On the other side he/she is different from a juvenile that is isolated, introvert and inert at home and less likely to contact with other minors in the neighborhood and also not to become delinquent [10]. Some authors have analyzed the role of juveniles as victims of domestic violence criminality, marriage violence [11] as victims of human trafficking [12], as victims from the persons with sociopathological behavior [13]. Also, they have analyzed the impact of the criminality and the fear of criminality regarding to the quality of life of the elderly and juveniles living in poor areas with a higher population density [14].

The author Azem Hajdari in his book Law of Criminal Procedure [15] elaborates extremely well the role of the legal expert, respectively the role of psychologist expert in criminal procedures under Kosovo legislation. Concerning juvenile delinquency, Miller [16] postulates lower-class culture as an autonomous cultural system and proclaims it as a circumstance that creates juvenile delinquency. Whereas Shabani \& Budimlić [17] have subdivided juveniles into many categories, such as: juveniles, adult juveniles, young adults and adults. However, some criminological research also classifies the distribution of criminality by age groups. The increasing prevalence of crime of domestic violence, crimes of violence against life and body, marriage violence, violence against children, violence against elderly and disabled parents, sexual crime and sexual violence, has created a need for more research work by experts to assist minors as victims or as witnesses in criminal and civil proceedings to assert their rights in accordance with national and international norms. Seeing this increase in national as well as regional and international aspects, the Albanian state adopted the Strategy for Juvenile Justice, accompanied by the action plan [18], which is at the same time the first policy document in this field for the long term period 2018-2021. Initially this document was planned for the period 2017-2020 but due to the establishment of a special structure for juveniles at the Ministry of Justice in November 2017, the deadline for its implementation has been postponed for the period 2018-2021.

It is surprising that the Kosovo government, namely the Ministry of Justice, has so far not sponsored any Juvenile Justice Strategy, associated with the action plan. However, regarding the assistance of minors in general, Office on Good Governance at the Office of the Prime Minister [19], has adopted the National Strategy and Action Plan for the Rights of the Child in the Republic of Kosovo 2009-2013. The Action Plan contains a number of key objectives and Juvenile Justice, where besides enlisting the assistance of a forensic psychologist at all stages of criminal and civil litigation, it also safeguards the best interests of the child in their physical and psychological development. The same Office on Good Governance office at the Office of the Prime Minister [20] also 
adopted the Strategy and Action Plan for Human Rights in the Republic of Kosovo (2013-2017), which advocated the strengthening of the role and capacity of the Kosovo Institutions, including the legislative, executive and judicial branches for the effective implementation of the legislation.

Kosovo legislation provides the juvenile with maximum protection in all procedures both investigative and judicial. These protections are guaranteed in all civil and criminal procedures. Thus, the role of the psychologist with the minor and his/her involvement in all procedural steps is important but at the same time a legal obligation is provided by the legal framework: the Constitution of Kosovo Article 29, paragraph 3, Article 31, paragraphs 3 and 7 [21].; The Criminal Code of Kosovo Articles 56 and 111, foresees special provisions for juveniles [22]; Criminal Procedure Code, Article 127 paragraph 1, Article 130 paragraph 5, Article 144, paragraph 7, Article 146 paragraphs 5 and 6 [23]; Juvenile Justice Code Article 4, paragraph 4, Article 11 paragraph 2, Article 13 paragraph 1 and 2, Article 16 paragraph 1, Article 20 paragraph 1.8, Article 28 paragraph 2.6, Article 40 paragraph 3, Article 43, Article 55 paragraph 3, Article 62 paragraph 3, Article 80 paragraph 2, Article 90 paragraph 3.2 and paragraph 8. Article 112 paragraph 1, 2 and 4, Article 119 paragraph 1.8, Article 126 paragraph 3 and 6 [7].

Furthermore, these legal provisions provide the role of the presence of a psychologist in all stages of criminal and civil procedures towards the minor. Criminal procedure towards a minor, such as interrogation by the prosecution authorities (police, prosecution) and the judiciary have been assessed as particularly important for its future by the Kosovo legal framework and therefore it was defined as one of the procedures that require the presence of a psychologist expert in pre-criminal and criminal procedures. The presence of this psychologist expert facilitates the investigation of the prosecution bodies to understand the juvenile, the reality in which the juvenile lives and the condition, in which he or she develops and forms. Also, in the procedural phases is the presence of a social worker or a sociologist, who with their work assist the psychologist expert by making their cooperation to create a complete and sustainable expertise, accurate and real.

The Law on Family of the Republic of Kosovo, articles 337 and 348, during contested procedures in the relations between parents and children [6] provides for the primary consideration of the child's highest interest by parents, competent bodies and the court, defining concrete tasks for parents, the State and society. In this context, in accordance with the UN Convention on the Rights of the Child article 3 and articles 29, 31 of the Constitution of Kosovo [21], the legislator expresses his/her full readiness to realize this interest of small through the intertwining of its mechanisms.

Specifically, the law on the family article 140, paragraph 1, stipulates that if the parents do not agree on the case, referred to in paragraph (1), or if their agreement does not correspond regarding to the interests of the child, the court after receiving the opinion and proposal of the Custodian Body and investigating all the circumstances, will decide: that all children must be left for custody and education to one parent, that some of them remain with the mother and some with the father, or that all or some children must be entrusted to a third person [6]. Before expressing an interim or final ruling on the right to exercise parental responsibility, the right to visit or to entrust the child care to one spouse, the court is obliged to call a psychologist or social worker, who contacts the minor and after hearing the statements or receiving information on the material and moral state of the child, gives an assessment of the minor's future. In the case of the dissolution of marriage, in determining, which of the parents will carry the minor for growth and education, the court in its decision shall consider the opinion of the psychologist or the social services sector at the local government unit, always after to have heard the minor [8].

Juvenile defendants in the psychology of criminal procedure are studied and analyzed with special attention and care, because in recent decades, especially this category is increasingly being brought in the court. And their deeds and mental states are very different from those of adult defendants and may be relevant to their long-term psychic development, which indirectly affects society as a whole [1].

Domestic violence in the last two decades in Kosovo is extremely widespread, there are many juveniles being attacked by this violence as the primary victims of perpetrators of criminal offenses, but it happens that during criminal procedures the prosecution authorities deliberately or unintentionally cause secondary victimization toward juveniles. But the concern is that more and more juveniles have been involved in the commission of criminal offenses lately. Therefore, as in the case of juvenile 
victimization, as in the case of perpetrators of criminal offenses, the role of the psychologist is very active also in the case of procedural steps that have as their object the violence in family relations, as it is provided in the Law on Protection from Domestic Violence, article 13, paragraphs 1.4 and 2.5 [24].

Kosovo's legal framework from the Constitution to various by-laws is in line with the Convention on the Rights of the Child, adopted by the General Assembly of the United Nations on 20 November 1989. Recalling the provisions of the Declaration on Social and Legal Principles relating to the Protection and Welfare of Children, in particular those concerning the placement of a child in a foster family and the adoption of the child at home and abroad; the United Nations Standard Minimum Rules on the Administration of Juvenile Justice (Beijing Rules) and the Declaration on the Protection of Women and Children in Periods of non-ordinary conditions and Armed Conflict [25].

The request for protection order for juveniles according to the Law on Protection from Domestic Violence, article 13, paragraph 1, may be submitted by: the protected party; the authorized representative of the protected party; victims advocate with the consent of the protected party; the representative of the center for social work in the municipality, where the protected party has his or her settlement or residence in cases, where the victim is a minor [24]. Whereas the request for an emergency protection order, according to the Law on Protection against Domestic Violence, article 13, paragraphs 2 and 3, may be filed by: the protected party; the authorized representative of the protected party; victim advocator with the consent of the protected party; the person, with whom the protected party has a family relationship; the representative of the center for social work in the municipality, where the protected party has settlement or residence in cases, where the victim is a minor; a person, who is directly aware of one or more acts of domestic violence against the protected party. Whereas NGOs, familiar with the victim's problem, well informed about its treatment, may also file the request for emergency protection orders [24].

Based on article 21, paragraph 2 of the Criminal Procedure Code, when a child is charged in a criminal case, that case will be separated from any other case and will only be dealt with by the Juvenile Department within the Basic Court under the Juvenile Justice Code [23]. This Code in article 154, paragraph 1 provides that during the statement, the accused of the pre-trial procedure have to ask questions about identity to his or her legal representative [23]. According to the Juvenile Justice Code, article 55, paragraph 3, during the investigative stages of the police, the prosecution and during the stages of court procedures, the interrogation of the minor in the cases when it's necessary, is undertaken with the assistance of a pedagogue, psychologist, defectologist or other expert [7]. During the court hearings, the proceeding authority hears the opinion of a psychologist or expert who, through hearings with juveniles enables him or her to assess his or her psychological, family, social and living conditions, thus explaining all the circumstances and facts, which can help the minor regarding to this issue. The psychologist or the doctor can give opinions, based on his or her education and experience. The psychologist or doctor may issue an expert report on their findings in accordance with Article 138 of the Juvenile Justice Code [7], but is not obliged by the law to do so.

When interrogating a minor, especially when he or she is a victim of a criminal offense, it should be taken care to ensure that the question does not adversely affect his or her mental state. Whenever the legal provision provides that he or she should be questioned in the presence of a psychologist, in this case questions are done with the assistance of a child psychologist or a pedagogue or other professional expert. The presence of a psychologist in criminal procedures is also evident when giving evidence to the police, prosecution and court.

For the purpose of solving disputes with accordance with the Juvenile Justice Code, Article 11, paragraphs 1 and 2 [7], provides for a juvenile mediator, who is a natural person that helps the parties to reach an agreement without the right to impose a solution for dispute in accordance with the principles of will, impartiality, equality of parties, transparency, efficiency and justice. A juvenile mediator can be an advocate, a lawyer, a social worker, a pedagogue and a psychologist. For minors is also guaranteed separation from adult detainees in the detention center. During this period of detention, psychological assistance by the psychologists of the center is offered for juveniles. 


\section{1. The role of the expert psychologist in the litigation}

The legal framework, both civil and criminal provides the juvenile with the presence of a psychologist or social worker at every procedural step, where he or she is a party in the procedure. The presence of a forensic psychologist provides assurances and guarantees to the juvenile for the proper conduct of procedures against him/her as a suspect, accused, or even as a witness. The presence of a psychologist expert is also very important in juvenile family matters, especially when dealing with very young juveniles.

Expertise is assigned when for ascertaining or assessing a relevant fact, the ascertainment and opinion of a specialist, who is in the relevant field and possesses the necessary professional knowledge, should be taken into consideration. The expertise shall be ordered by the court in writing upon the request of the public prosecutor, defense counsel or based on the official duties [26, p. 226]. The criminal Procedure Code, article 136, paragraph 2, provides that the psychologist expert through his/her sessions with the juvenile, in the end manages to give an opinion on the court, which is better for the juvenile. It should be noted, that the expert cannot express his or her opinion on the guilt or innocence of the defendant [23]. The expert testimony is one kind of evidence in the procedure. It usually constitutes of ascertainment and thoughts about the application of professional knowledge and skills by the expert in relation to the subject of the expertise. The expert's testimony must be relevant, concrete, clear, accurate, reliable, logical and convincing. Experts are obliged to comply with the rules of procedural actions and the rules of the profession, to which they belong, as well as to give the clear, complete and neutral, ie true opinion and ascertainment. The testimony may be presented in oral or written examination in front of the body of procedure. Expertise is a typical form of including in criminal procedures of extra-legal knowledge from various fields, primarily natural and technical.

Because of his or her professional qualities, the psychologist expert is summoned by the court in order to give a correct and concrete assessment for the personality of the juvenile within the dynamics of a family situation that conducts the so-called clinical conversation and makes recommendations to the court. Before the psychologist gives an opinion, he or she must obtain information about the material and moral status of the family, the conditions, in which the family lives, and where it is more suitable to live for the child. It decodes the thinking, behavior, reaction or withdrawal of a child who is experiencing a new, abnormal or traumatic situation [8, p. 11]

As the expertise or expert opinion is now subject to review by the court, this means that the psychologist expert in that public place is willing to demonstrate his or her professional opinion and justify his or her interpretation in order to persuasively show that his or her assessment comes closest to the truth of the concrete case.

Realizing that police investigators, prosecutors and judges may inadvertently cause secondary victimization during interrogation of a juvenile, charged with a criminal offense, as a victim or a witness, a psychologist expert or social worker is engaged in this case, helping the prosecution authorities in regard to examining the child's opinion. This expert also assists the aforementioned bodies in formulating correctly questions to minors without causing the secondary victimization.

In recent years police investigators have set up special rooms in some police stations to provide a more comfortable environment for minors. So they have been set television, computer, beds, games, colors, and different drawings, just to be careful not to traumatize or not to cause inadvertently secondary victimization during the interview in the presence of a psychologist.

The psychologist expert's knowledge from studies, specializations and work experience increases his/her capacity to understand and interpret the dynamics and psyche of the juvenile in various cases as a victim, accused but also as a witness in civil and criminal procedures. During criminal procedures the psychologist may propose various measures under the Criminal Code and the Juvenile Justice Code that will assist and be effective for the minor. All of these measures are preventive that will affect the rehabilitation of the minor for non-repetition of criminal offenses. Thus, the legal framework of Kosovo enables the judicial psychologist to know better the minor during his or her sessions and during his / her civil and criminal procedures and to assist him/her in various civil conditions and reports, such as adoption, custody etc., and help in criminal procedures during the conditions of his/her re-education and re-socialization. 
The expert psychologist's assessment is about the "whole" personality of the juvenile in a particular situation or in a particular aspect of such situation. In practice, very often even when isn't a request for the opinion about the "wholeness" of personality. It is really intended to analyze the possibility of the presence of a particular ability and of particular characteristics, which are not always a neutral professional description for the lawyer, but represent also a proposal for a defense or indictment thesis. In such a situation, the psychologist must be very restrained, calm and very careful in order to avoid the trap, in which he/she can "fall" him/herself (if he/she accidentally supports one party's arguments), because then can lose his/her professional position as a neutral expert and becomes a party to that dispute [1, p. 9].

\section{2. The various obstacles that are stagnating the work of juvenile prosecution bodies}

Lack of readiness by the competent authorities and permanent employment of clinical psychologists in police stations.

The lack of the competent bodies' readiness to employment of clinical psychologists in every directorate of the center for social work at the municipal level. This employment would further strengthen the assistance, provided by the Center for Social Work to Minors.

The victim as a plaintiff in the procedure, if he or she seeks the engagement of a psychologist expert, must pay at the outset in special cases by decision of the judge. The engagement of the psychologist expert in some special cases should be paid by both the plaintiff and the accused or by the convicted party in the case of criminal procedures.

There is a lack of the chamber of national psychologist experts and a list of psychologist experts.

Psychologist experts are selected for representation by judges and not by the chamber of psychologist experts that would be ranked (to dispel the suspicion of favors toward any psychologist expert according to the judge's preferences). This selection to be made by the chamber of expert psychologists would affect the objectivity of the procedures, developed in the prosecution bodies.

In most cases there is a lack of qualifications and training of psychologist experts in the field of clinical psychology to better assist juveniles in court procedures.

There is a lack of cooperation memorandum between psychologist experts and sociologists, working in the centers for social work in the municipalities.

The Assembly of Kosovo should adopt the Law on Psychological Activity

The professional exam should be established by law for expert psychologist, realized or supervised by the Ministry of Justice or chamber of expert psychologist. The professional exam should be consisted of the general and the professional part. The general part of the exam should be held in written examination and include: Law on Psychological Activity (will approve in the future), Code of Ethics of Psychological Activity, Labor Law and the Constitution of the Republic of Kosovo. While the professional part of the exam is oral and covers the knowledge and skills, gained through work experience. Also the professional part includes the form of problematic questions in the field that the intern has completed the internship.

Psychologist experts should be clear about their role in the justice system and should have evidence to support their ability to carry out professional activities that will be in the best interest of the juvenile, during their representation in a civil and criminal procedure.

\section{Conclusions}

Victims, accused and juvenile witnesses in the psychology of criminal procedure are studied and analyzed with particular attention and care because in recent years, especially this category is increasingly being presented at the police, prosecution and court. While their deeds and mental states are very different from those of adult defendants and may be relevant to their long-term psychic development, which indirectly affects society as a whole. Otherwise, this is observed in juvenile practice, whereby metamorphosis occurs (greater sincerity than in other age categories).

The involvement of a psychologist expert would guarantee the right of the juvenile in all procedural stages to a fair process both investigative and judicial. So, for equal representation as a procedural party before the court with respect for national and international rights and standards, guaranteed by normative acts and the Constitution of Kosovo. 
The employment of a psychologist expert in the tracking bodies as well as in the justice bodies would assist the work of the four bodies and would also assist the minor himself or herself, especially during various investigative stages, such as in the victim or witness position. This employment would also guarantee a long-term quality service by monitoring the problem and its solution. So, this hiring process of experts near these bodies would help the workers of these bodies to not inadvertently cause secondary victimization. In this way, in the future we would have faster integration of juveniles in the community.

The lack of qualifications, trainings, participation in national and international conferences was found to be very low. Psychologist experts in Kosovo, who contribute to the work of prosecution and justice bodies must be trained and qualified according to their specialization. Also, the professional work of psychologists was found to be work, which was not done in good professional conditions and environments, but often this work was done in accordance with the needs and requirements of tracking bodies of the police, prosecution and judicial bodies.

The training and specialization of psychologist experts near the tracking and justice bodies would give a new positive approach to the work of the tracking and judicial bodies in all procedural stages, both civil and criminal. This positive approach would guarantee the juveniles, but also the justice bodies for new solutions to the problem by avoiding violations of the human rights, guaranteed by the Constitution.

The Association of Psychological Experts, that we hope will be established in the future, should plan to hold trainings for Psychological Experts at the national and international level, so that their scientific knowledge can be enriched by the perfection of research techniques in different working conditions.

Kosovo in the future should be better prepared in the legislative system by amending the provisions of the Juvenile Justice Code to categorize psychological experts on the basis of their narrow specializations, all in order to increase the quality of expert psychologists during the work with minors.

Psychological experts should be employed in the main state bodies that have direct access to minors at all criminal and civil stages. Therefore, this involvement in the relevant institutions should be done in order to work more effectively with juveniles near the tracking bodies (police, prosecution,) and during court hearings also, in order to avoid unwitting secondary victimization or intentionally during the investigative phase, where juveniles are present as victims or as witnesses. Then regarding this we recommend the following:

- Employment of psychologist expert in police, prosecution and court for Permanent.

- Establishment of the Association of Psychologists with the aim of furthering in their profession and advancing the rule of law in Kosovo, by supporting the process of legal reforms, establishing high standards of professionalism, competence, confidence and ethical behavior for psychologist experts.

\section{References}

[1] Hasković, M. (2008). Psikologjia Forenzike. Sarajevë/Prishtinë.

[2] Vodinelić, V., Aleksić, Ž. (1990). Kriminalistika. Zagreb: Informator, 659.

[3] Kodi i Përkohshëm Penal i Kosovës (2003). Gazeta zyrtare, UNMIK/RREG/2003/25. Available at: http://gazetajnk.com/repository/docs/RA2003_25_CCintranet_295748.pdf Last accessed: 20.01.2020

[4] Kodi i Përkohshëm i Procedurës Penale i Kosovës (2003). Gazeta zyrtare, UNMIK/RREG/2003/26. Available at: https:// prokuroria-rks.org/assets/cms/uploads/files/Dokumente\%20Publikime/KPK/Legjislacioni/Kodi_i_procedures_penale.pdf Last accessed: 20.01.2020

[5] Regulation No. 2004/8 On the Juvenile justice Code of Kosovo. UNMIK. Available at: https://unmik.unmissions.org/sites/ default/files/regulations/02english/E2004regs/RE2004_08.pdf

[6] Ligji për Familjen i Kosovës (2006). Gazeta zyrtare, 4. Available at: https://gzk.rks-gov.net/ActDetail.aspx?ActID=2410 Last accessed: 15.02 .2020

[7] Kodi i Drejtësisë për të Mitur (2018). Gazeta zyrtare, 17. Available at: https://gzk.rks-gov.net/ActDetail.aspx?ActID=18019 Last accessed: 13.02.2020 
[8] Raporti i hartuar nga Qendra për Nisma Ligjore Qytetare (QNL) dhe Shërbimi Ligjor Falas (2014). Available at: http://www.qag-al.org/ Last accessed: 05.02.2020

[9] Hasković, M. (2006). Psikologjia. Sarajevë/Prishtinë.

[10] Maloku, A. (2020). Theory of Differential Association. Academic Journal of Interdisciplinary Studies, 9 (1), $170-178$. doi: http://doi.org/10.36941/ajis-2020-0015

[11] Halili, R. (2011). Kriminologjia. Prishtinë: Balmed.

[12] Maloku, A., Maloku, E. (2020). Protection of Human Trafficking Victims and Functionalization of Institutional Mechanisms in Kosovo. Acta Universitatis Danubius. Juridica, 16 (1), 21-44.

[13] Maloku, A. (2015). Alcoholism as a pathological social problem in the region of the municipality Gjilan-Kosovo. ICLS 2015. Pristina, 31.

[14] Maloku, A. (2015). Fear of Violence and Criminality in the Region of Gjilan, Kosovo. Mediterranean Journal of Social Sciences, 6 (2 S5), 29-36. doi: http://doi.org/10.5901/mjss.2015.v6n2s5p29

[15] Hajdari, A. (2013). E drejta e Procedure penale. Prishtinë: Kolegji Ilria.

[16] Miller, B.; Short, J. F. (Ed.) (1968). Walter: Lower class as a generating mileu of gang delinquency. Gang delinquency and gang subcultures. New York: Harper and Row, 135-136.

[17] Shabani, A., Budimilić, M. (2007). Kriminologjia. Sarajevë/Prishtinë.

[18] Strategjia e Drejtësisë për të Mitur dhe plani i veprimit (2018). UNICEF, 50. Available at: https://www.unicef.org/albania/ media/1501/file/National\%20Justice\%20for\%20Children\%20Strategy\%20Alb.pdf Last accessed: 04.02.2019

[19] Strategjinë dhe plani nacional i veprimit për të drejtat e fëmijëve në Republikën e Kosovës 2009-2013 (2009). Qeveria e Kosovës, zyrës e kryeministrit, 102. Available at: https://zqm.rks-gov.net/assets/cms/uploads/files/Strategjia\%20dhe\%20 plani\%20nacional\%20i\%20veprimit.pdf Last accessed: 13.11.2019

[20] Strategjia dhe plani e veprimit për të drejtat e njeriut në Republikën e Kosovës (2013-2017) (2013). Qeveria e Kosovës, zyrës e kryeministrit. Available at: http://www.kryeministri-ks.net/repository/docs/Pjesa_Narrative_e_Draft-Strategjise_per_te_ Drejtat_e_Njeriut_(2013-2017)_05_gusht_2013.pdf Last accessed: 23.11.2019

[21] Kushtetuta e Republikës se Kosovës (2008). Gazeta zyrtare, K-09042008. Available at: https://gzk.rks-gov.net/ActDetail.aspx?ActID=3702 Last accessed: 25.01 .2020

[22] Kodi Penal i Republikës së Kosovës (2019). Gazeta zyrtare, 2. Available at: https://md.rks-gov.net/desk/inc/media/6A2D43776AE1-4530-909F-3FB2680CD1EC.pdf Last accessed: 11.01.2020

[23] Kodi i Procedurës Penale (2012). Gazeta zyrtare, 37. Available at: https://gzk.rks-gov.net/ActDocumentDetail.aspx?ActID $=2861$ Last accessed: 15.01 .2020

[24] Ligj për Mbrojtje nga Dhuna në Familje (2010). Gazeta zyrtare, 76. Available at: https://gzk.rks-gov.net/ActDetail.aspx?ActID=2691 Last accessed: 05.12.2019

[25] Konventa mbi të Drejtat e fëmijës, miratuar nga Asambleja e Përgjithshme e Organizatës së Kombeve të Bashkuara më 20 nëntor 1989. Available at: https://www.unicef.org/montenegro/media/9291/file/MNE-media-MNEpublication505.pdf Last accessed: 18.12 .2019

[26] Hajdari, A. (2010). E drejta e procedurës penale. Prishtinë.

How to cite. Maloku E., Jasarevic O., Maloku A. (2021). Assistance of the psychologist expert inthe justice bodies to protect minors in kosovo. EUREKA: Health Sciences, (2), 52-60. https://doi.org/10.21303/2504-5571.2021.001649 